\title{
Politik Keshalehan Personal dalam Pemilihan Presiden 2014 dalam Media Sosial Twitter \\ Oleh:
}

\author{
Nurul Hasfi ${ }^{1}$
}

\begin{abstract}
Ekspresi beragama seringkali problematis, terutama saat berhadapan dengan dilema antara agama yang seringkali berseberangan dengan nilai demokrasi. Di area abu-abu seperti ini agama rentan disalahgunakan dalam kontestasi politik. Studi ini bertujuan mengeksplorasi peran agama dalam dalam proses komunikasi politik mengenai konstruksi kepemimpinan politik (political leadership) capres $2014 \mathrm{di}$ Twitter. Dengan menggunakan analisis wacana kritis studi ini menunjukkan adanya praktik sosial berupa politisasi agama yang bekerja melalui mekanisme politik keshalehan personal (politics of personal piety). Hal ini tersebut dilandasi temuan penggunaan nilai agama mayoritas (Islam) sebagai alat legitimasi kepemimpinan politik ideal dan sebaliknya penggunaan nilai-nilai agama/keyakinan minoritas untuk mengkonstruksi kepemimpinan politik tidak ideal. Hal ini menyiratkan bagaimana hegemoni agama dimanfaatkan secara sistematis untuk meraih kekusaaan politik. Dengan demikian peran agama dalam kontestasi politik di Twitter cenderung bersifat degradatif terhadap proses demokrasi. Hal ini disebabkan karena proses komunikasi politik gagal mendiskusikan nilai agama dengan prosedur dialog netral.
\end{abstract}

Kata kunci : Pilpres, politik keshalehan personal, Twitter

\begin{abstract}
Religious expressions are often problematic, especially when faced with a dilemma between religions that are often opposed to democratic values. In this gray area, religion is vulnerable to misuse in political contestation. This study aims to explore the role of religion in the process of political communication on Twitter about construction of political leadership during 2014th presidential election. Using the critical discourse analysis of this study shows the existence of social practices of religious politicization working through the mechanism politic of personal piety. The conclution is based on the findings of the use of majority religius value (Islam) as a legitimacy tool for representing ideal (good) political leadership and in contrast the use of minority religion values/ beliefs to constructing bad political leadership. This implies how religious hegemony is used systematically to achieve political power. Thus, the role of religion in political contestation on Twitter tends to be degradative to the democratic process. This is because the political communication process fails in discussing religius value from the perspective of neutral dialogue procedures
\end{abstract}

Keywords: Presidential election, politics of personal piety, Twitter

\section{A. Latar Belakang}

Kepemimpinan politik (political leadership) merupakan isu yang selalu menjadi perdebatan terutama dalam kontestasi politik seperti pemilihan presiden bahkan di setiap negara. Dalam negara demokratis idealnya kriteria seorang pemimpin politik merupakan sosok yang demokratis yakni kepemimpinan yang dilekati dengan karakterkarakter yang memposisikan dirinya sebagai pelayan rakyat. Berdasarkan studi empiris yang dilakukan oleh Hacker, 2004; Kinder et al., 1980; Miller, Wattenberg \&Malanchuk, 1986; Treneman \& McQuail, 1961 (dalam Barisione, 2009) kriteria kepemimpinan politik demokratis meliputi

\footnotetext{
${ }^{1}$ Nurul Hasfi merupakan staf pengajar di Departemen Ilmu Komunikasi FISIP Undip Semarang. Menyelesaikan studi Doktor pada program pascasarjana Ilmu Sosiologi FISIPOL UGM (2013-2017).
} 
Jurnal Pemikiran Sosiologi Volume 4 No. 2, 2017

Politik Keshalehan Personal dalam Pemilihan Presiden 2014 dalam Media Sosial Twitter

Nurul Hasfi

kompetensi, kekuatan, reliabilitas, integritas, kemampuan, kedekatan dengan rakyat. Kriteria kepemimpinan demokratis tersebut idealnya menjadi patokan dalam proses pemilihan kepala negara di negara demokratis karena merupakan karakter berdasar yang mampu menjamin pemimpin untuk menjalankan tugas dan amanahnya demi kepentingan seluruh rakyat.

Namun pada kenyataannya kriteria kepemimpinan politik demokratis tersebut tidak selamanya dapat diterapkan sepenuhnya oleh setiap negara demokrasi karena masing-masing memiliki konteks kultural spesifik yang membentuk praktik demokrasi yang khas. Kepemimpinan politik ideal di Indonesia misalnya lebih merujuk pada kriteria kultural seperti beridentitias Islam (Syamsudin, 1993); ber-ethnis Jawa (Irawanto, Philip \& Ryan, 2011; Syamsudin, 1993; Freeland, 2007; Nadeau, 1993) dan berlatar-belakang Militer (Syamsudin, 1993; Kim, R. William, Salim, 2006). Bahkan dalam sebuah negara demokrasi terbesar di dunia sepertiAmerika Serikat, agama selalu terlibat dalam mimbar politik pemilihan presiden. Dalam pemilu presiden 2008, Obama direpresentasikan mediamedia Amerika sebagai kandidat presiden Muslim yang merupakan neraga minor di Amerika Serikat.

Dalam konteks politik Indonesia, akhir-akhir ini nilai agama nampaknya semakin sering dipakai sebagai alat legitimasi idealitas sosok pemimpin politik dimana salah satunya bekerja melalui mekanisme konstruksi kepemimpinan religius. Fenomena ini semakin masif dilakukan dengan adanya media baru dalam hal ini media sosial dimana wacana-wacana dapat diproduksi dan didistribusikan dengan cepat. Studi ini berfokus pada proses komunikasi politik di Twitter yang mengkonstruksi kepemimpinan politik dari perspektif agama. Dengan menggunakan konteks pemilihan presiden 2014 yang kental dengan nuansa kontestasi ideologi agama dan etnisitas studi ini ingin melihat bagaimana nilai-nilai agama dimainkan mengkonstruksikepemimpinan politik. Dari sini pula peneliti kemudian diharapkan dapat mengidentifikasi permasalan proses demokrasi Indonesia dari perspektif keterlibatan agama dalam proses demokratisasi. Penelitian ini menjadi penting dilakukan karena konteks penelitian yakni Indonesia merupakan sebuah negara demokrasi dengan agama plural sehingga perlu untuk melihat bagaimana agama berdialog dengan prinsip demokrasi.

Namun demikian, penulis perlu menekankan bahwa keterlibatan agama dalam proses demokrasi disini bukan keterlibatan secara nyata, namun keterlibatan agama dengan dimediasi oleh internet yakni media sosial Twitter. Proses semacam ini dalam studi demokrasi disebut sebagai cyberdemocracy dan digital democracy berkembang di abad 21 seiring dengan fenomena Computer Mediated Communication (CMC). Hacker and van Dijk (2000: 2 dalam Moyo, 2009) mendefinisikan demokrasi digital sebagai tujuan kolektif untuk mempraktekkan demokrasi tanpa batasan ruang, waktu dan persyaratan fisik lain dengan menggunakan Information Communication and Technology (ICT).Sementara Dijk mendefinisikan demokrasi digital sebagai praktik demokrasi dengan cara apapun yang dilakukan dengan menggunakan media digital termasuk internet. Meski demikian studi ini tidak berfokus pada studi demokrasi digital namun lebih pada bagaimana nilai-nilai religiusitas dilibatkan dalam proses demokrasi digital tersebut. 
Jurnal Pemikiran Sosiologi Volume 4 No. 2, 2017

Politik Keshalehan Personal dalam Pemilihan Presiden 2014 dalam Media Sosial Twitter

Nurul Hasfi

Untuk melihat hubungan agama dengan proses demokrasi maka perlu melihat hubungan agama dengan negara. Sebagaimana dibahas para ahli demokrasi, relasi antara agama dan negara seringkali problematis karena keduanya berada pada ranah yang berbeda yakni ranah privat dan publik. Dalam melihat posisi agama dalam praktik berdemokrasi, penulis menggunakan pandangan Habermas (dalam Aur, 2014: 86-87) yang mengakui adanya akar religius dari negara hukum demokratis. Pandangan ini dipakai salah satunya terkait erat dengan konteks penelitian ini yakni demokrasi di Indonesia yang tidak pernah terpisah dari wacanawacana agama. Namun demikian, penulis juga menekankan pada pandangan Habermas selanjutnya yang menyebut bahwa keterlibatan agama dalam proses demokrasi tidak lantas menjadikan agama sebagai basis negara hukum demokrasi. Dalam hal ini, praktik berdemokrasi tidak bertumpu pada agama namun pada prinsip demokrasi itu sendiri. Dengan prinsip ini, maka kehidupan bernegara tidak mendasarkan diri pada berbagai pengandaian kosmologis. Negara tidak memihak pada kelompok agama tertentu, namun melihat seluruh kelompok agama setara dalam memainkan perannya dalam proses politik. Dengan pandangan ini maka kelompok agama baik itu mayoritas maupun minoritas memiliki kesempatan dan ruang yang sama dalam proses berdemokrasi.

\section{B. Metode Penelitian}

Untuk melihat peran agama dalam konstruksi kepemimpinan politik calon presiden, studi ini menggunakan metode Critical Discourse Analysis (Fairclough, 1992, 34). Metode ini melihat teks tidak sekedar informasi, namun teks merupakan praktik sosial salah satunya praktik kekuasaan. Ada tiga langkah analisis yang harus dilakukan yakni; 1) analisis teks; 2) analisis diskursif praktis; 3) analisis sosio-kultural.Tahap ke-1 analisis teks berfokus pada identifikasi tentang representasi kepemimpinan politik calon presiden 2014 dari perspektif agama yang dibangun akun-akun Twitter pro Jokowi dan pro Prabowo. Ada dua perbedaan mendasar antara karakter teks Twitter dengan teks media tradisional yang mengharuskan peneliti modifikasi teknik analisis teks CDA; 1) Teks Twitter bermakna lugas dan minim simbol berbeda dengan teks media tradisional yang dikonstruksi sedemikian rupa sehingga sarat dengan makna dan simbol tersembunyi. Konsekuensinya, ada tahapan analisis teks yang tidak banyak dilakukan yakni analisis bahasa atau semantik, karena tanpa banyak melakukan analisis pada elemen tersebut, peneliti sudah dapat membaca makna tersembunyi dalam teks; 2) Produksi teks di Twitter berlangsung cepat dan tak terbatas, namun memiliki makna yang dangkal. Berbeda dengan teks media tradisional yang terbatas namun memiliki makna mendalam. Konsekuensinya, peneliti harus mengambil rentang waktu cukup lama dalam pengambilan sampel agar dapat menangkap pola percakapan antar akun terkait isu yang sedang diteliti yakni konstruksi kepemimpinan politik dari perspektif nilai-nilai agama.

Tahap ke-2 yakni analisis praktik diskursif (discourse practice) berfokus pada identifikasi proses produksi dan konsumsi representasi kepemimpinan politik yang telah terbangun. Pada tahapan ini ada hubungan saling mempengaruhi antara berbagai hal yang disebut Fairclough sebagai 
Jurnal Pemikiran Sosiologi Volume 4 No. 2, 2017

Politik Keshalehan Personal dalam Pemilihan Presiden 2014 dalam Media Sosial Twitter

Nurul Hasfi

member resources (MR). ${ }^{2}$ MR ini diinternalisasikan oleh para pemproduksi wacana di dalam teks yang meninggalkan seperangkat isyarat untuk proses interpretasi peneliti. Dalam konteks penelitian ini, MR yang dimaksud yakni konteks (historis, politik, sosial budaya) yang menjadi konteks dan latar belakang mengapa suatu teks diproduksi demikian.

Analisis sosio-kultural (socio-cultural) dalam penelitian ini berfokus pada satu upaya yakni mengindentifikasi praktik kekuasaan yang terendap pada representasi kepemimpinan politik calon presiden 2014 yang telah ditemukan pada tahap 1 . Tahap ini membantu peneliti dalam menginterpretasikan bagaimana praktik hegemoni agama beroperasi melalui teks representasi kepemimpinan politik calon presiden 2014. Dari sini pula peneliti dapat mengidentifikasi peran agama dalam proses demokrasi di ruang maya ini.

Sementara itu, teks yang menjadi obyek penelitian ini yakni tweet yang diproduksi oleh 8 akun Twitter terpilih yang aktif memproduksi dan mendiskusikan wacana kepemimpinan politik calon presiden dari perspektif nilai agama. Akun-akun tersebut juga memiliki pengikut (follower) lebih dari 50.000 pengikut.

\section{Konstruksi Kepemimpinan Politik Ideal: Pemimpin yang Shaleh}

Berdasarkan analisis teks terhadap obyek studi, ada dua mekanisme yang dipakai untuk mengkonstruksi kepemimpinan politik religius yakni menggunakan nilai agama mayoritas dan nilai agama minoritas. Temuan utama studi ini memperlihatkan nilai-nilai agama mayoritas digunakan untuk mengkonstruksi kepemimpinan politik yang ideal, sementara nilai agama minoritas digunakan untuk mengkonstruksi kepemimpinan politik yang tidak ideal. Selanjutnya akan kita jabarkan satu persatu bagaimana masingmasing nilai agama dipakai sebagai alat legitimasi kedua calon presiden untuk meng-klaim religuisitasnya. Tweet-tweet yang dipilih untuk artikel ini merupakan tweet yang menjadi perbincangan di semua akun Twitter yang menjadi sampel penelitian ini, yang diasumsikan paling banyak mendapatkan perhatian dari netizen.

Aktifitas ibadah agama Islam berupa 'sholat'dan segala hal terkait dengan sholat merupakan alat paling sering dipakai akun pro Jokowi untuk mengkonstruksi keshalehan personal calon presiden di Twitter. Hal ini terutama dilakukan oleh akun-akun Twitter pihak Jokowi untuk mengcounter wacana Jokowi non-Muslim atau Jokowi Katolik yang masif tersebar di ruang maya.

dan kehidupan sosial tempat dia berada seperti nilai (values), kepercayaan (beliefs), asumsi, dan lain sebagainya (Fairclough,1989: 24)
2 MR didefinisikan sebagai sesuatu yang ada di kepala produser saat mereka memproduksi teks - termasuk pengetahuan mereka, representasi mereka atas obyek 


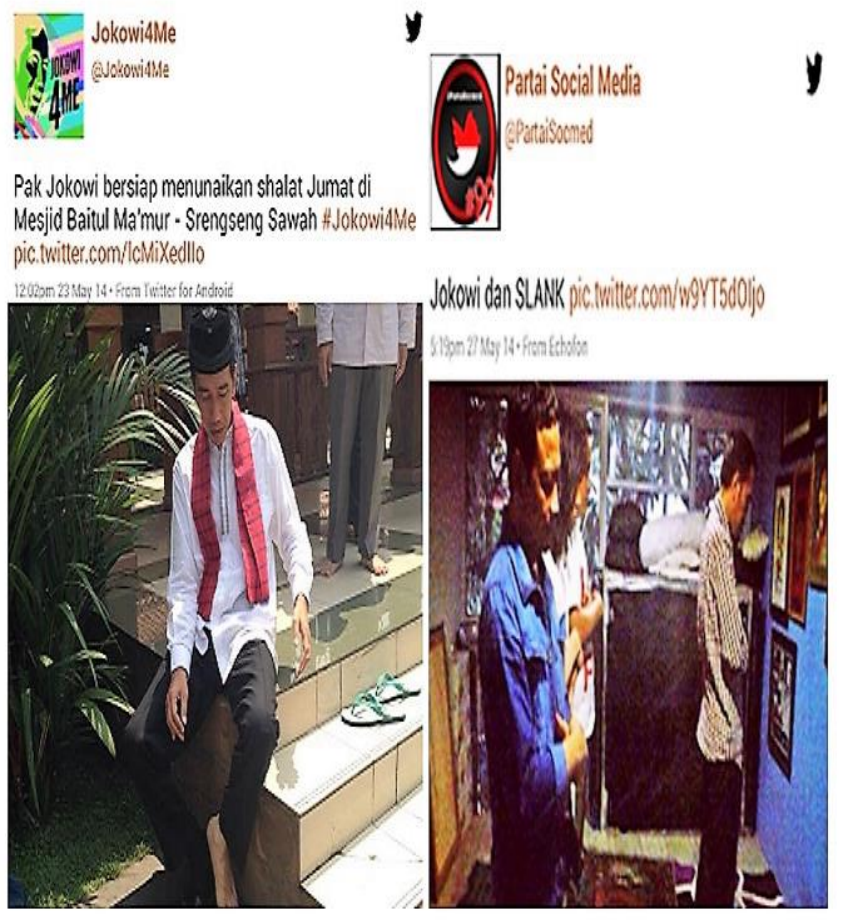

Gambar 01. Tweet tentang Representasi Keshalehan Jokowi (Sumber data primer)

Tweet pertama dibuat oleh @Jokowi4Me yang memperlihatkan Jokowi sedang melepas sandal untuk menjalankan ibadah sholat Jumat. Selain merepresentasikan Jokowi sebagai calon presidenshaleh, tweet ini juga sedang menkonstruksi kesederhanaan Jokowi yang duduk di lantai depan masjid layaknya masyarakat biasa. Sementara tweet disampingnya dibuat oleh @PartaiSocmed dan@Jokowi4Me yang memperlihatkan Jokowi yang menjadi imam sholat saat berkunjung ke markas band kenamaan SLANK yang menjadi simpatisannya. Menjadi imam sholat ini terutama dipakai untuk men-counter wacana 'Jokowi tidak bisa menjadi imam sholat' yang disebatkan akun pseudonym @TrioMacan2000. Salah satunya tweet berikut ini.
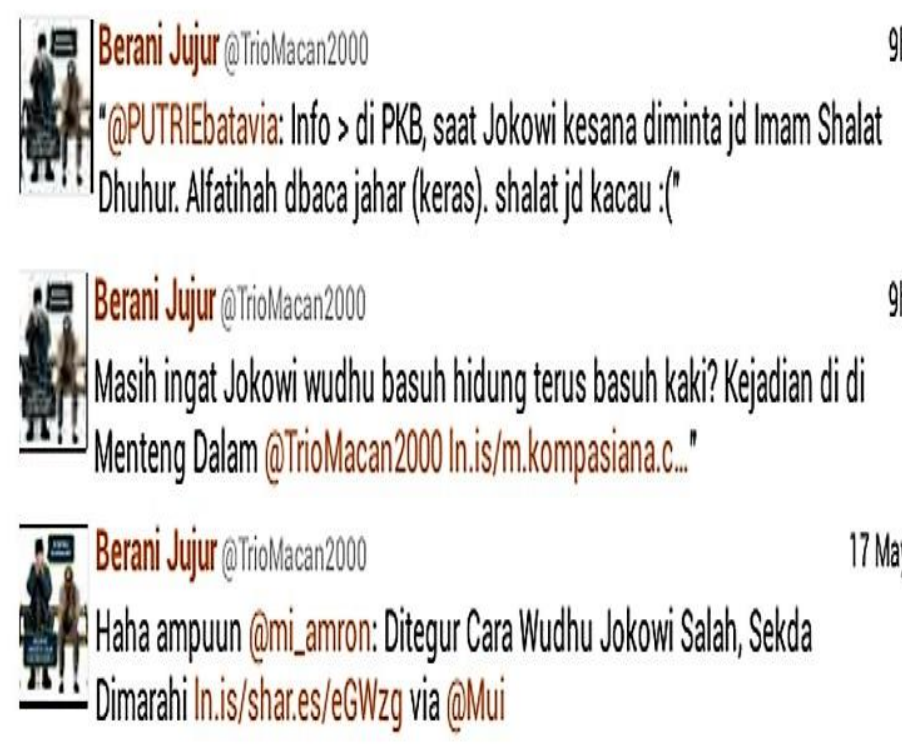

17 May

Gambar 02. Tweet tentang 'Wacana Tanding' (counter) Jokowi tidak bisa jadi Imam Shalat (Sumber data primer)

Dalam konteks ini sedang terjadi perdebatan klaim kebenaran tentang keimanan Jokowi dilihat dari kemampuannya dalam menjalankan ibadah sholat sebagai salah satu rukun Islam. Rukun Islam merupakan lima tindakan dasar dalam Islam yang pondasi keimanan seorang muslim. Tweet di atas menegaskan ketidak-mampuan Jokowi dalam berwudhlu yang dalam Islam menjadi syarat syahnya Sholat merefleksikan Jokowi bukanlah muslim religius. Wacana tesebut bisa dikatakan menjadi wacana dominan yang muncul dalam perbincangan politik hingga pihak Jokowi butuh untuk membangun wacana balasan. Selain membuat tweet-tweet tentang Jokowi yang bisa sholat dan ber-wudhu, akun-akun pro Jokowi juga menggunakan testimoni public figure untuk meyakinkan kepada khalayak tentang kemampuan sholat Jokowi, diantaranya kesaksian Din Syamsuddin dan Jusuf Kalla. 


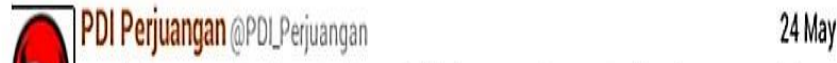 "Dari niat sampai salam, \& a hamamdulillah semua benar \& tok ada yang salah dgn beliau," kata Oin Syamsuddin menyoal tata cara shalat J Jokowi}
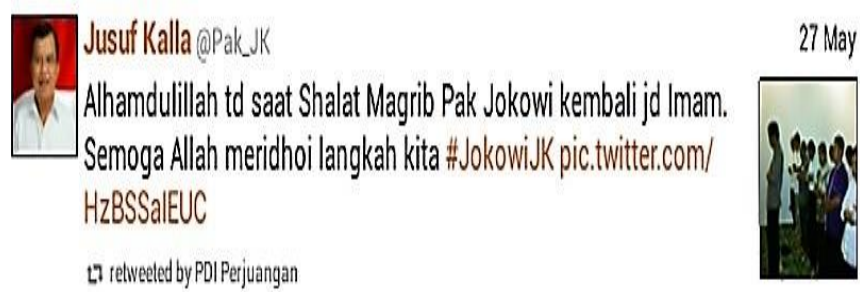

Gambar 03. Tweet Testimoni JK tentang Jokowi sebagai Imam Shalat (Sumber data primer)

Tweet @PDI_Perjuangan menggunakan kesaksian Din Syamsuddin dan calon presiden Jusuf Kalla untuk membuktikan bahwa Jokowi sudah melakukan tata cara sholat dengan benar. Kedua tokoh Islam tersebut dianggap kompeten untuk melegitimasi kemampuan sholat Jokowi karena mereka tokoh Islam yang disegani masyarakat Indonesia dan orang-orang yang ada di dekat Jokowi. Bahkan karena gencarnya serangan negatif terhadap Jokowi, Jusuf Kalla yang merupakan calon pendamping Jokowi merasa perlu membuat pernyataanya melalui akun Twitter pribadinya $@$ @ak_JK yang kemudian di-retweet akun pendukung Jokowi termasuk @PDI_Perjuangan.

Selain kemampuan dalam menjalankan sholat dan wudlu, representasi religiusitas Jokowi juga dibangun dengan menggunakan kemampuannya

\footnotetext{
3 Kitab kuning merupakan salah satu khasanah Islam yang dipakai di pesantren-pesantren tradisional di Indonesia (Nahdlatul Ulama). Kitab ini disebut sebagai sumber intelektual Almarhum Gus Dur, yang konon
}

dalam membaca ayat-ayat Al-Quran atau mengaji sebagaimana terlihat pada tweet berikut ini.

\section{t.7. PDI Periuangan retweeted} Jokowi For All @ Q JokowiLall RT Q @merdekadotcom: Jokowi dan ketua dewan syuro PKB ngajj kitab Kuning mok:to/:tym2 \#Peristiwa

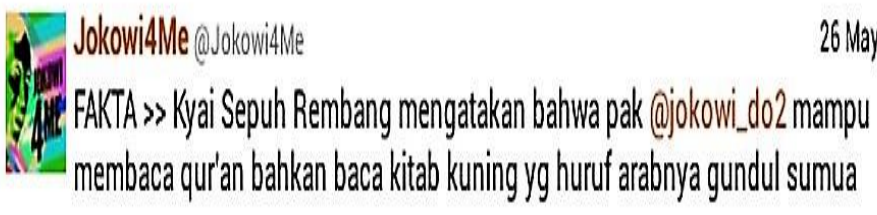

Gambar 04. Tweet 'Kemampuan Membaca Al Qur'an' Jokowi

Tweet diatas sedang mengkonstruksi sosok Jokowi sebagai pemimpin politik yang ideal karena bisa mengaji. Kedua tweet di atas sama-sama berisi kesaksian Kyai Mansyur yang mengatakan bahwa Jokowi bisa membaca kitab kuning. Tweet pertama ter-link dengan berita media online merdeka.com berjudul 'Jokowi dan ketua dewan syuro Partai Kebangkitan Bangsa ngaji kitab kuning '. 3 Terdapat petikan wawancara seperti di bawah ini:

.."Pak Jokowi membaca Jamul Jawami. Salah satu kitab (kuning) yang berisi tentang fikih (hukum) syariat orang Islam," kata Kiai Mansyur yang juga ketua dewan syuro Partai Kebangkitan Bangsa ini usai menerima kunjungan Jokowi di Jombang, Jawa Timur, Sabtu (3/5)....

Pernyataan Kyai Mansyur ini menjadi klaim kuat bahwa Jokowi beragama Islam dan mengerti tentang hukum syariat Islam. Dengan tweet ini

kaidah yang terkandung di dalamnya telah banyak dipakai sebagai sarana untuk memecahkan permasalahan-permasalahan bangsa 
Jurnal Pemikiran Sosiologi Volume 4 No. 2, 2017

Politik Keshalehan Personal dalam Pemilihan Presiden 2014 dalam Media Sosial Twitter

Nurul Hasfi

@PDI_Perjuangan tidak hanya sedang mencitrakan Jokowi sebagai calon presiden yang religius karena bisa mengaji Kitab Kuning namun sedang menunjukkan bahwa Jokowi merupakan calon presiden yang mengetahui isi kitab Kuning yakni 'fikih syariat Islam'. Hal tersebut merepresentasikan Jokowi sebagai pemimpin Islami.

Sementara itu, tweet berikut ini dipakai akun-akun pro Jokowi untuk merepresentasikan keshalehan Jokowi dengan menggunakan ibadah Haji dan Umroh. Jokowi direpresentasikan sebagai pemimpin politik yang ideal bagi bangsa Indonesia karena ia telah melakukan kedua ibadah tersebut. Sama dengan konstruksi keshalehan pribadi dengan menggunakan ibadah sholat, wudlu dan mengaji, reprentasi ini juga secara sistematis dibangun untuk menangkal kampanye negatif yang menyerang religiusitas Jokowi yakni Jokowi Katolik dan Jokowi tidak bisa beribadah. Secara khusus, tweet tentang Jokowi naik Haji terutama dikonstruksi untuk mengcounteradanya wacana bahwa inisial $\mathrm{H}$ yang ada didepan nama Jokowi merupakan nama babtis Jokowi yakni Herbertus yang mengkonstruksi Jokowi sebagai orang Katolik.

PDI Perjuangan @Pol_erjuangan Jokowi: Hitu haji, bukan Herbertus koranbanten.com/2014/05/jokowi.. \#JokowiJk

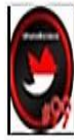
Partai Social Media (aPartaisocmed Ini waktu masih di solo @Pro_Perubahan: Foto pak Jokowi (paling kiri) naik haij bareng Tantowi Yahya (paling kanan) pic.twitter.com/ PWTXPUNkzn

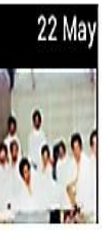

Gambar 05. Tweet 'Penjelasan arti H sebagai gelar Haji' untuk Jokowi bukan nama baptis Heribertus (Sumber: data primer).
Tweet diatas memperlihatkan bahwa pembuktian Jokowi sudah Haji dilakukan dengan berbagai cara diataranya dengan konfirmasi yang dilakukan melalui akun resmi Partai Demokrasi Indonesia Perjuangan @PDI_Perjuangan, penggunaan foto bukti Jokowi naik Haji tahun 2003 yang diunggah oleh@PartaiSocmed serta menggunakan link-link pemberitaan-pemberitaan media online (koranbanten.com, kompas.com) yang membenarkan Jokowi beragama Islam dan telah naik Haji. Religiusitas juga tidak sebatas dibangun dengan konstruksi terhadap pribadi calon presiden namun juga konstruksi terhadap keluarga sebagaimana terlihat pada tweet berikut ini.
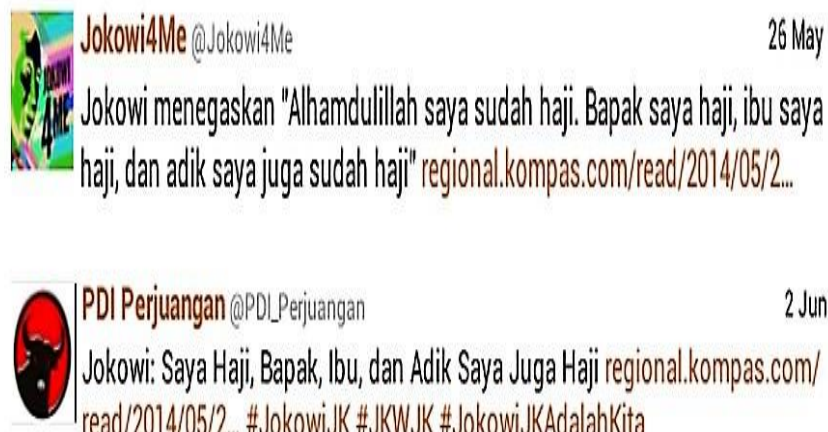

PDI Perjuangan (PPDI Peijuarigan

2Jun Jokowi: Saya Häi, Bapak, Lbu, dan Adik Saya Juga Haji regional.kompas.com/ read/2014/05/2... \#JokowiJK\#JUKJK\#JokowiJKAdalahKita

Gambar 06. Tweet tentang 'Religiusitas Keluarga Jokowi' (Sumber data primer)

Nilai agama lain yang juga digunakan untuk mengkonstruksi kepemimpinan religius calon presiden yakni tentang puasa. Video yang dimuat di dua tweet di bawah ini merupakan cuplikan berita yang disiarkan oleh Metro TV saat mewawancarai Jokowi mengenai makna bulan Ramadhan. Jawaban Jokowi yang ragu, tidak lancar dan patah-patah dimanfaatkan akun @TrioMacan2000 untuk mempertanyakan ke-Islam-an Jokowi. Pada saat itu Jokowi masih menjabat sebagai Gubernur DKI. 


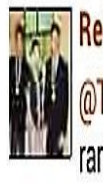

ReizaMahenduaP (oheizanP

Q)TrioMacan2000 can pendapatnya can "jokowi gagap ketika di tanya makna ramadhan," di YouTube - youtube.com/watch? $v=$ _pXOAg...

L7 retiveeled by Beranilujuf

Gambar 07. Tweet yang menyebarkan berita bohong tentang Jokowi yang suka Klenik

Tweet pertama terkait dengan artikel berjudul 'Kisah Klenik Jokowi dan Ki Gunung Kemukus' yang ada di media online gebraknews.com. Tanpa melihat isi artikel ini, tweet @TrioMacan2000 ini melekatkan Jokowi dengan ritual seks untuk pasugihan dan kesuksesan dunia di Gunung Kemukus, Sragen, Jawa Tengah. Jika meminjam istilah Geertz (1960) Jokowi sedang dikonstruksi sebagai kelompok Abangan yang mempercayai ritual-ritual klenik dan syirik yang tidak sesuai dengan nilai-nilai Islam.

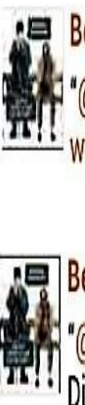

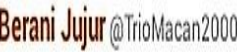

"Gburunghantu1913: Kisah Klenik Jokowi dan Ki Gunung Kemukus In.is/ www.gebraknews..."

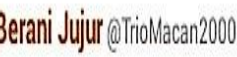
Dirinya In.is/www.gebraknews..."

Gambar 08. Tweet lanjutan yang mengkonstruksi Jokowi suka Klenik (Musyrik)
Paparan tentang konstruksi kepemimpinan politik Jokowi yang dibangun dengan menggunakan wacana religiusitas agama diatas merefleksikan bahwa akun-akun Jokowi merepresentasikan Jokowi sebagai calon presiden yang shaleh dengan menggunakan alat legitimasi berupa kemampuan Jokowi dalam menjalankan ibadah agama Islam. Ibadah yang dimaksud diantaranya sholat (menjadi imam, sholat Jumat), mengaji, menunaikan Haji dan Umroh. Wacana dipakai untuk meng-counter wacana calon presiden Jokowi sebagai calon presiden yang tidak bisa menjadi imam sholat, salah melaksanakan wudlu yang gencar disebar di ruang nyata. Konstruksi keshalehan calon presiden Jokowi juga secara sistematis menggunakan alat legitimasi berupa kesaksian public figure tentang ke-Islam-an Jokowi. Selain dua metode diatas, legitimasi keshalehan Jokowi dilakukan dengan memanfaatkan pemberitaan positif tentang hal tersebut yang dimuat berita online dengan cata menyebarkan link-link berita tersebut di Twitter.

Sementara itu, pihak Prabowo bisa dikatakan tidak banyak mengkonstruksi wacana 'keshalehan personal'. Hal ini disebabkan karena citra shaleh telah kuat dilekatkan oleh dukungan partai-partai Islam yang berkoalisi dengan Gerindra. Namun demikian, pihak konstruksi kepemimpinan Prabowo tetap tidak lepas dari penggunaan alat-alat legitimasi religiusitas sebagaimana yang terjadi pada Jokowi sebagaimana terlihat pada twit-twit berikut ini. 


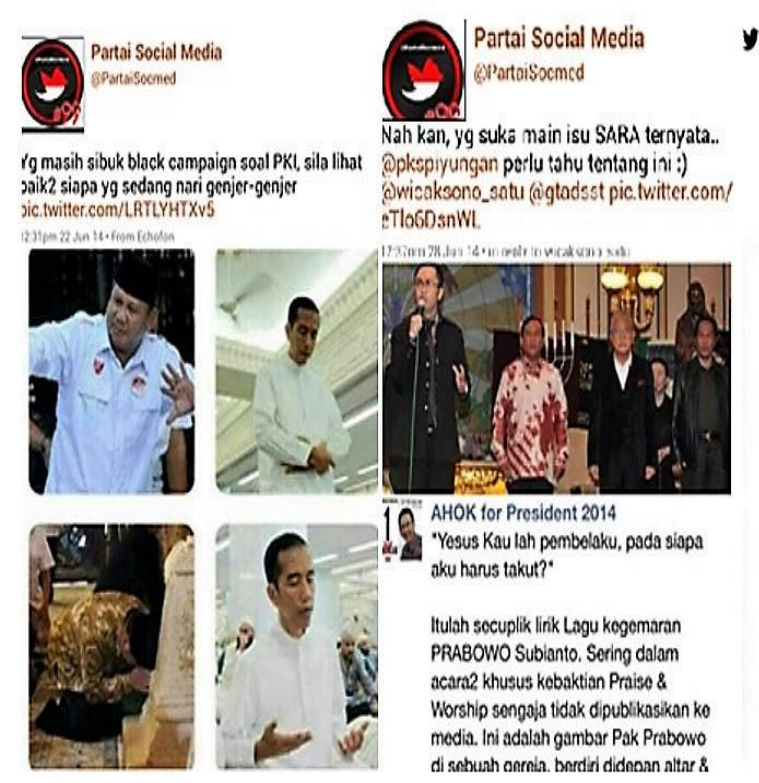

Gambar 09. Tweet Kampanye Hitam Citra Buruk Prabowo (Sumber: data primer)

Sebagaimana Jokowi yang mendapatkan serangan dengan menggunakan wacana religiusitasnya, Prabowo juga mendapatkan serangan yang sama. Twit pertama sosok Prabowo digambarkan sebagai tidak religius karena terlihat sedang menari yang dalam tweet diatas disebut menari 'genjer-genjer', lagu yang idetik dengan simbol Partai Komunis Indonesia (PKI) yang menggunakannya sebagai alat propaganda tentang penderitaan rakyat kecil. Prabowo juga direpresentasikan sedang menyembah makam yang dianggap dalam Islam merupakan tindakan syirik. Kedua foto Prabowo tersebut disandingkan dengan foto Jokowi yang direpresentasikan sedang menunaikan sholat dan berdoa di dalam masjid.

Sementara Twit kedua dibuat @partaisocmed untuk meng-counter isu SARA yang menyerang Jokowi dangan menggunakan Ahok. Teks memperlihatkan akun sosial media bernama AHOK for President 2014 menceritakan bahwa Prabowo menyukai lagu gereja. Disitu juga disebut Prabowo sedang berdiri di depan altar sebuah gereja, atau tempat suci agama Katolik/ Protestan. Dua Twit ini sedang mengkonstruksi Prabowo calon presiden yang tidak religius dalam konteks Islam.

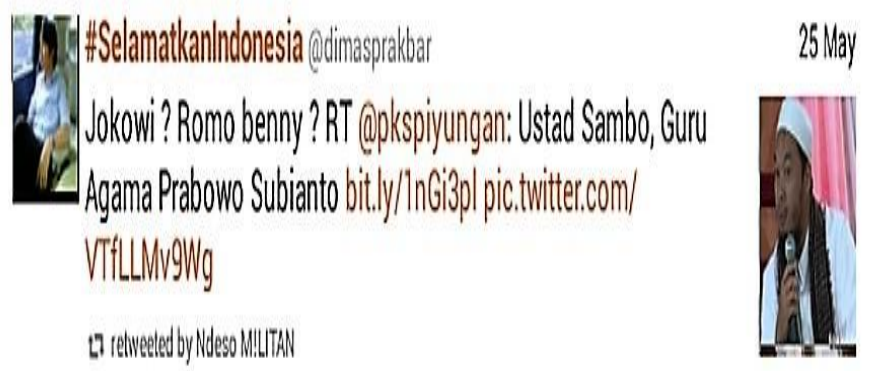

Gambar 10. Tweet 'Konstruksi Keshalehan Prabowo' (Sumber: data primer)

Sementara itu, tweet diatas lebih membangun representasi positif Prabowo sebagai sosok religius dengan alat legitimasi berupa kedekatannya dengan seorang Ustad. Wacana tersebut dikontraskan dengan sosok Jokowi yang direpresentasikan memiliki penasehat religius seorang Romo. Tabel dibawah ini menjelaskan hasil analisis teks Twitter yang telah dipaparkan diatas. 
Jurnal Pemikiran Sosiologi Volume 4 No. 2, 2017

Politik Keshalehan Personal dalam Pemilihan Presiden 2014 dalam Media Sosial Twitter

Nurul Hasfi

\begin{tabular}{|c|c|c|c|}
\hline \multicolumn{2}{|c|}{ Alat Legitimasi } & \multicolumn{2}{|c|}{ Konstruksi Kepemimpinan Politik } \\
\hline & & Capres Ideal & Capres Tidak Ideal \\
\hline $\begin{array}{l}\text { Nilai-nilai } \\
\text { Islam }\end{array}$ & $\begin{array}{l}\text { Sholat:Sholat Jumat, } \\
\text { Azan, Wudhu, Iman } \\
\text { Sholat, Azan, Bacaan } \\
\text { Alquran }\end{array}$ & $\begin{array}{l}\text { - Bisa menjadi imam } \\
\text { sholat } \\
\text { - Sholat teratur } \\
\text { - Bisa membaca Alquran } \\
\text { dan kitab Kuning } \\
\text { - Takbir } \\
\text { - Janji Jumatan Keliling }\end{array}$ & $\begin{array}{l}\text { - Tidak bisa menjadi } \\
\text { Iman Sholat } \\
\text { - Tidak Sholat Jumat } \\
\text { - Tak bisa berwudhu } \\
\text { - Berhenti Orasi saat ada } \\
\text { Azan }\end{array}$ \\
\hline & Puasa & $\begin{array}{l}\text { Mengetahui Makna } \\
\text { Puasa Ramadhan }\end{array}$ & $\begin{array}{l}\text { Tidak mengetahui Makna } \\
\text { Puasa Ramadhan }\end{array}$ \\
\hline & Haji; Umroh & $\begin{array}{l}\text { - Sudah ber-Haji dan } \\
\text { Umroh } \\
\text { - Keluarga capres sudah } \\
\text { ber-Haji }\end{array}$ & $\begin{array}{l}\text { - Salah memakai Ihram } \\
\text { saat umrah }\end{array}$ \\
\hline $\begin{array}{l}\text { Nilai } \\
\text { Agama } \\
\text { Minoritas }\end{array}$ & - & $\cdot$ & $\begin{array}{l}\text {-Kebaktian di Gereja } \\
\text {-Ritual tradisional } \\
\text { (Abangan) } \\
\text {-Dekat dengan Pendeta }\end{array}$ \\
\hline
\end{tabular}

Tabel 01. Politik Keshalehen Personal - Politics of Personal Piety (Sumber: Analisis Teks Twitter 1 Mei - 9 Juli 2014)

Calon presiden yang ideal bagi masyarakat Indonesia didefinisikan sebagai sosok beragama Islam yang taat dan bisa beribadah. Ibadah yang dimaksud seperti sholat, membaca Alquran, ber-haji dan ber-umroh, puasa dan lain sebagainya. Sebaliknya, calon presiden yang tidak ideal bagi bangsa Indonesia yakni sosok beragama Islam yang tidak taat dan tidak bisa beribadah serta memiliki kedekatan dengan simbol-simbol agama non-Islam dan keyakinan minoritas. Tabel ini menunjukkan bagaimana nilai agama Islam kental dipakai sebagai alat konstruksi kepemimpinan politik dari perspektif religius kental. Hal ini tidak cukup memberikan ruang kontestasi pada nilai-nilai agama minoritas seperti nilai-nilai agama Budha dan Hindu yang tidak dilibatkan, dan nilai-nilai agama Katolik dan Kristen yang lebih dipakai sebagai alat mengkonstruksi kepemimpinan politik yang buruk bagi masyarakat Indonesia. Dari formasi ini nampak nilai agama Kristen dan Katolik merupakan pesaing bagi nilai Islam, sementara nilai Hindu dan Budha lebih dianggap tidak berkontribusi apapun dalam proses kontestasi politik para aktor yang sedang bersaing.

\section{Politik Keshalehan Personal: Marginalisasi Nilai Agama/ Kepercayaan Minoritas}

Fenomena sebagaimana terlihat pada Tabel 01 menunjukkan bagaimana nilai agama diperankan sebagai sarana untuk mengkonstuksi kepemimpinan politik religiusitas untuk kepentingan politik yang dalam studi ini kemudian disebut sebagai politik keshalehan personal (politics of personal piety). Dalam politik keshalehan personal, nilai-nilai agama berperan sebagai sarana untuk meraih, merebut dan mempertahankan kekuasaan berupa kemenangan dalam pemilihan presiden 2014. Politik keshalehan personal merupakan konsep yang telah lama dipakai dan tidak hanya terjadi di Indonesia. Menurut Luiselli (2008: 1) istilah keshalehan personal (personal piety) pertama kali dipakai Adolf Erman tahun 1911 dan James Henry Breasted 1992. Pada saat itu, 'keshalehan personal' digunakan untuk menggambarkan manifestasi keyakinan dan praktik agama secara pribadi di era Mesir Kuno, berfokus pada pembahasan tentang usaha melihat hubungan antara manusia dengan ilahi (Tuhan) di periode Ramesside (1295-1069 SM). Keshalehan personal dalam studi ini digunakan untuk mengkonstruksi 
Jurnal Pemikiran Sosiologi Volume 4 No. 2, 2017

Politik Keshalehan Personal dalam Pemilihan Presiden 2014 dalam Media Sosial Twitter

Nurul Hasfi

kedekatan para calon presiden dengan Tuhan dari perpektif Islam sebagai agama mayoritas.

Sejauh ini, berdasarkan penelusuran dari berbagai literatur baik jurnal nasional maupun internasional, tidak menemukan konsep keshalehan politik yang dipakai studi berkonteks pemilihan presiden. Namun, beberapa peneliti telah membangun teori keshalehan personal ini di area politik diantaranya Mahmood $(2005,24)$ menggunakan istilah politik of piety untuk membahas tentang gerakan Islamisasi (da'wah) terhadap kaum perempuan di Mesir. Keshalehan yang dimaksud diantaranya penggunaan jilbab, peningkatan keinginan melakukan ritual Islam dan amalan Islam. Sementara dalam studi ini keshalehan dikaitkan dengan tirual Islam dan amalan Islam yang lebih dikenal sebagai rukun Islam. Jika yang Mahmood melihat politik keshalehan untuk mempengaruhi masyarakat agar memeluk Islam (Islamisasi), maka studi ini menemukan bahwa keshalehan personal digunakan sebagai alat meraih kekusaan politik.

Sementara itu, Leege \& Kellstedt (1993, 217) membahas konsep keshalehan pribadi dalam konteks yang lebih dekat dengan penelitian ini yakni perilaku politik di Amerika yang memandang bahwa keshalehan pribadi merupakan hal penting dalam praktik politik di Amerika. Menurutnya perilaku keagamaan seorang individu seperti kejujuran, integritas, keshalehan dan perhatian kepada orang lain mencerminkan apakah orang itu bisa dipercaya di pasar ekonomi maupun pemerintahan. Artinya dalam masyarakat Amerika, keshalehan - dalam perspektif agama mayoritas di Amerika - seorang calon pemimpin menentukan kepercayaan masyarakat padanya.Temuan studi ini ternyata juga merefleksikan bagaimana keshalehan personal diyakini para politisi dapat dipakai untuk membujuk pilihan politik masyarakat Indonesia.

Sebagaimana yang telah disebutkan sebelumnya, sudut pandang keshalehan personal dalam studi ini berangkat dari sudut pandang Islam sebagai agama mayoritas di Indonesia. Ada dua ruang lingkup definisi keshalehan personal dari sudut pandang Islam (Yurwanto, 2014; Riadi, 2014).Pertama, keshalehan personal diartikan sebagai setiap tindakan individu dalam menjalankan rukun Islam (syahadat, sholat, puasa, zakat, haji). Dengan demikian konstruksi definisi calon presiden yang shaleh yakni mereka yang bisa menjalankan dan taat menjalankan rukun Islam. Dari definisi ini peneliti mengartikan politik keshalehan personal sebagai segala tindakan menggunakan nilai dan ritual rukun Islam sebagai alat untuk mencapai kekuasaan. Kedua, Islam juga mendefinisikan bahwa keshalehan personal Muslim pada hubungan vertikal antara manusia dengan Tuhan (hablum minallah), dimana keshalehan personal ini menuntut lahirnya hubungan harmonis antara sesama manusia yang disebut keshalehan sosial (hablum minannas). Hubungan antara sesama dalam keshalehan sosial diartikan sebagai terbentuknya individu yang menjadi khalifah (wakil Allah), pencipta kedamaian dan kebersamaan. Cara berfikir inilah yang manjadi landasan argumen masyarakat mengapa seorang pemimpin yang ideal haruslah mereka yang memiliki kashalehan personal yang kuat. Analoginya, hanya sosok yang taat kepada Allah saja yang mampu membawa kedamaian dan kebersamaan masyarakat Indonesia.

Fenomena tentang keshalehan personal calon presiden merefleksikan adanya hegemoni ideologi kelompok Islam di Indonesia yan disebut Geertz 
Jurnal Pemikiran Sosiologi Volume 4 No. 2, 2017

Politik Keshalehan Personal dalam Pemilihan Presiden 2014 dalam Media Sosial Twitter

Nurul Hasfi

(1960) sebagai golongan 'Santri'. Hegemoni disini menekankan tentang telah terhadinya naturalisasi nilai Islam, dalam hal ini nilai-nilai keshalehan Islam, yang tidak perlu diperdebatkan lagi kebenarannya baik oleh masyarakat Islam dan bahkan oleh masyarakat non-Islam. Sementara itu, hegemoni nilai-nilai agama kelompok santri sebagaimana disebut diatas, tersirat dari penggunaan alat legitimasi berupa ritual-ritual Islam milik kelompok Santri sepertisholat, puasa, zakat, haji, membaca Alquran dan lain sebagainya. Praktik sosial ini mengkonstruksi makna dimana pemimpin politik yang ideal bagi bangsa Indonesia adalah sosok yang mewakili kalangan Santri. Menurut Geertz, Santri merupakan kelompok Islam di Indonesia yang memiliki tradisi kuat dalam menjalankan ritual Islam tersebut dibandingkan dengan dua kelompok lain yakni abangan dan priyayi. Geertz (1952, 289 301) juga menjabarkan ibadah yang dimaksud dengan sembahyang, sholat Jumat, puasa, menjalankan haji dan umroh sebagaimana yang muncul dalam alat legitimasi konstruksi sosok calon presiden ideal. Dengan demikian nilai-nilai agama diluar kelompok santri - abangan, priyayi, nonmuslim, sekuler, liberal dan lain sebagainya merupakan kelompok yang termarginalkan.

Adanya kaitan praktik politik keshalehan personal dengan pandangan Geertz tentang fakta sosial mengenai relasi kuasa antara nilai-nilai agama yang ada dalam budaya Indonesia mencerminkan bahwa konstruksi kepemimpinan religius dalam pemilu presiden tidak lepas dari konteks sejarah dimana kepemimpinan politik terbentuk. Lebih jauh, jika dirunut dari kontekslain yakni sejarah kekuasaan politik Islam di Indonesia, maka konstruksi kepemimpinan politik religius dari perspektif Islam ini juga terkait erat dengan peran strategis kelompok Islam dalam politik di Indonesia, bahkan sejak Era Pra Kemerdekaan. Islam yang dipeluk oleh mayoritas masyarakat Indonesia memiliki andil besar dalam meraih kemerdekaan. Pertama, peran strategis Islam dalam perjuangan membebaskan masyarakat Indonesia dari belenggu penjajahan Belanda menonjol saat para pedagang muslim mendirikan Sarekat Islam (Suryadinata, 1971; Carey, 1984; 7). Sarekat Islam bermula dari organisasi Sarekat Dagang Islam yang sebelumnya hanya untuk kepentingan perdagangan para pedagang Islam namun berkembang menjadi organisasi yang bergerak dibidang sosial dan politik. Kedua, Islam juga berperan besar pada masa prakemerdekaan terutama dalam sidang BPUPKI dimana Islam terlibat dalam revisi 'Piagam Jakarta'. Pada saat itu tepatnya 22 Juni 1945 Panitia Sembilan berhasil merumuskan pembukaan UUD 1945 yang oleh Muhammad Yamin disebut sebagai 'Piagam Jakarta'. Sila pertama Pancasila yang ada pada pembukaan UUD 45 ini berbunyi 'Ketuhanan Yang Maha Esa dengan Kewajiban Menjalankan Syariat Islam bagi Pemeluknya'. Menjelang pengesahan UUD 45 atas prakarsa Muhammad Hatta, frasa 'Dengan Kewajiban Menjalankan Syariat Islam bagi Pemeluknya' dihapus karena adanya aspirasi dari Indonesia timur yang mayoritas beragama Katolik dan Protestan. Setelah perdebatan panjangpada akhirnya empat tokoh Islam yang terlibat dalam diskusi yakni Ki Bagus Hadikusumo, Wahid Hasyim, Kasman Singodimejo dan Teuku Hasan menyetujui penghapusan frasa ekslusif tersebut (Soeprapto, 2013; 8). Hingga pada akhirnya sila pancasila mengandung nilai universal yakni 'Ketuhanan Yang Maha Esa'. 
Jurnal Pemikiran Sosiologi Volume 4 No. 2, 2017

Politik Keshalehan Personal dalam Pemilihan Presiden 2014 dalam Media Sosial Twitter

Nurul Hasfi

Keberhasilan para tokoh Islam dalam memberikan ruang bagi nilai agama lain dalam proses kehidupan bernegara menjadi simbol perjuangan pluralisme kelompok Islam bagi kesatuan bangsa. Dalam konteks studi ini, nilai-nilai pluralisme agama yang telah ditanamkan para tokoh Islam di era itu kini justru teracam dengan munculnya wacana-wacana primordial Islam yang salah satunya dipakai untuk mengkonstruksi sosok kepemimpinan politik religius sebagaimana ditemukan dalam studi ini.

\section{E. Kegagalan Demokrasi: Dialog antar Nilai-nilai Agama}

Politik keshalehan personal yang memunculkan dilematis dalam proses berdemokrasi sebagai temuan penelitian ini pada dasarnya bukan fenomena yang hanya terjadi di Indonesia. Bahkan di negara demokrasi terbesar di Indonesia seperti Amerika, religiusitas calon presiden juga menjadi isu kampanye yang selalu diperdebatkan. Pew Research Center ${ }^{4}$ mengatakan bahwa dalam sejarah pemilihan umum di Amerika, warganya tidak pernah memilih presiden yang tidak religius dan ateis (tidak beragama). Sebagian besar dari warga Amerika secara konsisten mengatakan bahwa seorang presiden harus memiliki keyakinan agama yang kuat.

Dalam pemilihan presiden 2008, media online di Amerika ramai mempertanyakan tentang agama Obama yang memiliki latar keluarga yang tinggal di

$4 \quad$ http://www.pewforum.org/2016/01/27/faith-andthe-2016-campaign/

5 http://thehill.com/blogs/ballot-box/presidentialraces/284281-trump-questions-clintons-religion berbagai negara salah satunya Indonesia, sebagai negara Muslim terbesar di dunia. Menjelang pemilihan umum Amerika Serikat 8 November 2016, wacana tentang keshalehan personal calon presiden juga menjadi alat konstruksi kepemimpinan calon presiden misalnya thehill.com ${ }^{5}$ yang membuat berita berjudul 'Trump Questioning Clinton's Religion' (21/06/2016). Berita ini berisi pernyataan kandidat presiden dari partai Demokrat, Donald Trump, yang mempertanyakan komitmen ke-Kristen-an rival beratnya, Hillary Clintons. Sementara itu, lembaga penelitian di Amerika Pew Research Center setidaknya dalam dua periode pemilihan umum USA - 20086 dan 20167melakukan survey 'religiusitas' para kandidat presiden yang memperlihatkan betapa pentingnya isu ini bagi pemilih.

Sementara dalam konteks politik di Indonesia, idealitas kepemimpinan Islam telah menjadi naturalisasi dalam masyarakat politik kita, namun pola-pola konstruksi kepemimpinan politik yang secara masif menggunakan politik keshalehan personal sebagaimana ditemukan di Twitter nampaknya baru dominan muncul terutama di era digital ini. Politik keshalehan personal era digital yang menonjolkan kekuasaan agama dominan dan membatasi ruang bagi nilai agama marginal untuk terlibat dalam diskusi mencerminkan bagaimana demokrasi kini berhadapan dengan tantangan baru.

Studi ini mengidentifikasi permasalahan dilema agama dalam demokrasi digital tersebut dengan

\footnotetext{
6 http://www.pewforum.org/2007/09/06/clinton-andgiuliani-seen-as-not-highly-religious-romneys-religionraises-concerns/

7 http://www.pewforum.org/2016/01/27/faith-andthe-2016-campaign/
} 
Jurnal Pemikiran Sosiologi Volume 4 No. 2, 2017

Politik Keshalehan Personal dalam Pemilihan Presiden 2014 dalam Media Sosial Twitter

Nurul Hasfi

menggunakan perspektif Habermas (Aur, 2014: 86-

87) tentang hubungan agama dengan kehidupan bernegara. Habermas mengakui adanya akar religius dari negara hukum demokratis yang memiliki rasio sekuler yakni agama diperbolehkan terlibat dalam proses demokrasi. Ini artinya politik agama memiliki ruang dalam proses demokrasi sebagaimana yang terjadi di Indonesia saat ini. Namun demikian, Habermas memberikan penekanan bahwa basis negara hukum demokrasi tidak bertumpu pada agama (Aur, 2014: 86-87) tetapi bertumpu pada prinsip demokrasi itu sendiri. Dengan prinsip ini, maka kehidupan bernegara tidak mendasarkan diri pada berbagai pengandaian kosmologis sehingga semua agama yang ada dalam sebuah negara memiliki posisi yang sama. Dengan demikian dalam perspektif ini bisa diinterpretasikan bahwa meskipun agama dapat bebas terlibat dalam proses demokrasi di Indonesai namun masingmasing agama pada dasarnya memiliki kewajiban untuk menjaga eksistensi agama lainnya.

Jika memandang pada prinsip tersebut, maka dalam sebuah negara demokrasi dengan agama plural seperti Indonesia, konstruksi kepemimpinan politik calon presiden 2014 seharusnya tidak bertumpu pada alat legitimasi berupa nilai agama dominan saja namun seharusnya juga melibatkan nilai agama lain. Berdasarkan temuan penelitian (Tabel 01) prinsip tersebut belum sepenuhnya berlangsung dalam proses konstruksi kepemimpinan politik 2014 di Twitter dimana religiusitas sosok pemimpin lebih didefinisikan dari satu sudut pandang yakni nilai religiusitas agama mayoritas. Prinsip-prinsip primordialisme agama bahkan salah satu pengendali utama proses perdebatan wacana sosok kepemimpinan politik religius bagi bangsa
Indonesia. Peneliti melihat keterlibatan nilai agama dalam proses komunikasi politik belum diimbangi niat para aktor demokrasi untuk mentransfomasi agama mistis ke agama rasional. Dilibatkannya agama dalam proses konstruksi kepemimpinan politik di Twitter dari perspektif relegius ini kental dengan nuansa konflik ideologis antar agama yang justru membahayakan persatuan dan kesatuan bangsa.

Secara spesifik penulis mencoba mengurai lebih dalam mengenati temuan politik keshalehan personal dengan menggunakan sebuah prosedur komunikasi yang disebut Habermas (1996, 309311) sebagai'dialog netral'. Prosedur ini dipakai sebagai tolok ukur sebuah diskusi politik di ruang demokratis manakala melibatkan nilai-nilai agama. Dalam dialog netral, diskusi politik selalu dilatarbelakangi olehargumen-argumen universal dan bukan oleh argumen partikular agama. Ketika dua kelompok agama sedang bertikai tentang suatu nilai, maka untuk menyelesaikannya masing-masing kelompok agama tidak bisa mendasarkan penilaian pada nilai-nilai khusus yang dimiliki suatu agama, namun harus didasarkan pada nilai universal yang bisa diterima semua agama. Dalam konstruksi kepemimpinan politik religius misalnya konstruksi sosok religius seharusnya lebih didasarkan pada kriteria universal misalnya jujur, berperikemanusiaan, santun, mengayomi dan nilai universal lainnya dibanding kriteria didasarkan pada syarat-syarat berupa kemampuan dan ketaatan dalam menjalankan ibadah agama tertentu.

Dalam studi ini argumen universal muncul dalam konstruksi kepemimpinan politik calon presiden2014 di Twitter, namun argumen partikular agama yang ternaturalisasi dalam sebuah 
Jurnal Pemikiran Sosiologi Volume 4 No. 2, 2017

Politik Keshalehan Personal dalam Pemilihan Presiden 2014 dalam Media Sosial Twitter

Nurul Hasfi

praktik hegemoni muncuk secara dominan dan membeku menjadi nilai kebenaran dalam masyarakat Indonesia. Hal ini menyebabkan argument berbasis keyakinan partikular agama menjadi kebenaran yang dianggap tidak perlu didiskusikan lagi. Jika demikian maka kekuasaan agama dengan mudah dapat disalahgunakan aktoraktor politik untuk kepentingan mencapai kekuasaan. Pada akhirnya nilai-nilai agama yang seharusnya berfungsi memperkaya perdebatan politik dalam masyarakat demokratis justru mendegradasi proses demokrasi.

Lebih lanjut, Habermas (dalam Hardiman, 2009; 157-158) menyediakan prinsip untuk menjamin berlangsungnya dialog netral yakni tuntutan terhadap tiga aktor demokrasi yakni negara, kelompok religius dan kelompok minoritas religius/ sekuler untuk saling memberi ruang bagi diskusi universal. Prosedur 'netralitas dialog' akan berjalan dengan baik manakala kekuasaan ketiganya terdistribusi secara merata dalam tiga ruang yakni ruang milik negara, milik kelompok religius dan milik kelompok minoritas agama dan sekuler. Masing-masing aktor dituntut menjalankan perannya secara seimbang sehingga pada akhirnya dialog politik di antara ketiganya berlangsung deliberatif, infkusif dalam ruang yang egaliter. Dengan demikian, jika dilihat hasil studi ini yang menunjukkan dominasi nilai agama mayoritas atas nilai agama minoritas maka dapat dikatakan bahwa dialog netral dalam konteks konstruksi kepemimpinan politik religius gagal dilakukan karena tidak adanya ruang memadahi bagi nilai-nilai agama minoritas dan sekuler untuk terlibat dalam kontestasi politik.

\section{F. Kesimpulan}

Berdasarkan temuan penelitian diatas studi ini menunjukkan bahwa nilai-nilai agama terlibat aktif dalam proses kontestasi politik pada konstruksi kepemimpinan politik religius di Twitter yang disebut penulis sebagai politik keshalehan personal (politics of personal piety). Politik keshalehan personal beroperasi dengan menggunakan nilai agama mayoritas yakni Islam yang mendefinisikan kepemimpinan politik yang ideal sebagai sosok yang mampu dan taat menjalankan rukun Islam. Nilai Islam ini dalam proses politik Indonesia telah ternaturalisasi dalam masyarakat politik di Indonesia dan secara tidak langsung telah meminggirkan dan mengeluarkan (exclude) nilainilai agama/kepercayaan minoritas dari ruang diskusi politik di ruang maya. Politik keshalehan personal merefleksikan kegagalan dari kegagalan kontestan politik dalam menerapkan prosedur demokrasi yang disebut Habermas sebagai dialig netral. Kegagalan dialog netral ini terjadi saat perdebatan politik lebih menggunakan landasan argumen religius dalam perspektif nilai-nilai partikular agama yang primordial dan bukan berangkat dari argumen religius dari sudut pandang nilai-nilai universal yang dapat diterima semua agama.

Dari temuan tersebut dapat disimpulkan bahwa dalam konteks khusus yakni diskusi politik tentang kepemimpinan politik religius yang dimediasi oleh Twitter dalam pemilihan presiden 2014, hubungan agama dan demokrasi masih problematik. Praktik demokrasi liberal yang saat ini lebih dominan berlangsung di Indonesia memberikan ruang tak terbatas bagi nilai-nilai agama untuk diekspresikan sebagai bentuk dari Hak Asasi Manusia yang 
Jurnal Pemikiran Sosiologi Volume 4 No. 2, 2017

Politik Keshalehan Personal dalam Pemilihan Presiden 2014 dalam Media Sosial Twitter Nurul Hasfi

dilindungi oleh demokrasi. Namun disisi lain, kebebasan tersebut juga secara bersamaan telah mencederai proses demokrasi karena pada praktiknya ada keterlibatan nilai partikular agama yang secara sadar atau tidak sadar telah meminggirkan nilai agama/kepercayaan minoritas. Dari studi ini, penulis melihat, nilai-nilai Islam sebagai nilai agama mayoritas masyarakat Indonesia akan selalu menjadi tantangan dalam proses demokrasi politik di Indonesia. Hal ini disebabkan karena Islam merupakan agama terbesar di Indonesia sehingga logikanya akan menjadi ideologi dominan yang menjadi acuan. Hal yang perlu diwaspadai yakni manakala hegemoni Islam mulai mengarah pada penggunaan nilai-nilai primordialisme agama yang justru mendegradasi dan mendestruksi proses demokrasi di Indonesia yang pluralis ini.

\section{Daftar Pustaka}

Aur, Alexander. 2014. "Dialog Negara Hukum Demokratis dan Agama: Memotret Deliberasi Politik Berbasis Agama di Indonesia dengan Perspektif Filsafat Politik Jurgen Habermas." Jurnal Ultima Humaniora, Vol II, Nomor 1 (Maret 2014): 79-97

Barisione, Mauro. 2009. "Valence Image and the Standardisation of Democratic Political Leadership." Leadership Vol 5(1): 41-60 DOI:10.1177/1742715008098309 http://lea.sagepub.com

Carey, Peter. 1984. "Changing Javanese Perceptions of the Chinese Communities in Central Java 1755-1825, " Indonesia Vol. 37

Dijk, Jan A.G.M. 2013."Digital Democracy: Vision and Reality," dalam I. Snellen \& W. van de Donk (eds), Public Administration in the Information Age: Revisited. Amsterdam: IOSPress

Fairclough, Norman.1992. Discourse and Social Change. Cambridge: Polity Press
Fairclough, Norman.1989. Language and Power. New York: Longman Inc

Freeland, Felicia Hughes.2007. "Charisma and Celebrity in Indonesian Politics". Anthropological Theory. Vol 7(2): 177-200. DOI:10.1177/1463499607077297

Geertz, Clifford. 1960. Abangan, Santri, Priyayi dalam Masyarakat Jawa. Jakarta: PT. Djaya Pirusa

Hardiman, Budi.2009. Kritik Ideologi: Menyingkap Pertautan Pengetahuan dan Kepentingan Bersama Jurgen Habermas. Yogyakarta: Kanisius

Habermas, J.1996. Between Facts and Norms: Contributions to a Discourse Theory of Law and Democracy. Cambridge: Polity Press.

Irawanto, Dodi Wirawan, Phillip L. Ramsey \& James C. Ryan. 2011. "Tailoring Leadership Theory to Indonesian Culture". Global Business Review. 12(3) 355-366. DOI:10.1177/097215091101200301 http://gbr.sagepub.com

Kim, Yong Cheol, R. William Liddle, Salim Said. 2006. "Political Leadership and Civilian Supremacy in Third Wave Democracies: Comparing South Korea and Indonesia". Pacific Affairs. Vol. 79, No. 2 (Summer,): 247-268 URL:http://www.jstor.org/stable/4002269 1. Diakses pada 28 Juni 2016.

Luiselli, Michela.2008. Personal Piety (Modern Theories Related To). California: University of California Press.

Leege \& Kellstedt. 1993. Agama dalam Politik Amerika. Jakarta: Mizan bekerjasama dengan Freedom Institute dan Kedutaan Besar Amerika Serikat

Mahmood, Saba. 2005. Politics of Piety: The Islamic Revival and the Feminist Subject. Princeton and Oxford: Princeton University Press

Moyo, Last .2009. "Digital Democracy: Enhancing the Public Sphere", dalam Creeber \& Martin (eds), Digital Culture: Understanding New Media. London: Open University

Nadeau, Kathy. 1993. "Looking For Lords Charismatic Authority and Modernization in Central Java". Philippine Quarterly of Culture and Society, Vol. 21, No. 4 (December 1993): 382-387

Pew Research Center. 2016. Faith and the 2016 Campaign GOP candidates seen as religious except for Trump. Diakses dari laman http://www.pewforum.org/2016/01/27/fa ith-and-the-2016-campaign/. Diakses pada 23 Maret 2017. 
Jurnal Pemikiran Sosiologi Volume 4 No. 2, 2017

Politik Keshalehan Personal dalam Pemilihan Presiden 2014 dalam Media Sosial Twitter Nurul Hasfi

Pew Research Center. 2016. Clinton and Giuliani Seen as Not Highly Religious; Romney's Religion Raises Concerns. Diakses dari laman http://www.pewforum.org/2007/09/06/cl inton-and-giuliani-seen-as-not-highlyreligious-romneys-religion-raisesconcerns/. Diakses pada 23 Maret 2017.

Riadi, Haris. 2014. "Kesalehan Sosial Sebagai Parameter Kesalehan Keberislaman (Ikhtizar baru dalam menggagas mempraktekkan tauhid sosial)". Jurnal Pemikiran Islam, Vol. 39, No. 1, Januari - Juni. Suryadinata, Leo. 1971. "Pre-War Indonesian Nationalism and the Peranakan Chinese". Southeast Asia Program Publications No. 11: 83-94. Diakses melalui Cornell University Stable URL: http://www.jstor.org/stable/3350745. Diakses pada 10 Juni 2017.

Syamsuddin, M. Din. 1993. "Political Stability and Leadership Succession in Indonesia". Contemporary Southeast Asia, Vol. 15, No. 1 (June 1993): 12-23

The Hill. 2016. Trump questions Clinton's religion. Diakses dari laman http://www.pewforum.org/2016/01/27/fa ith-and-the-2016-campaign/. Diakses pada 23 Maret 2017

Yurwanto, Yedi. 2014. "Memaknai Pesan Spiritual Ajaran Agama dalam Membangun Karakter Kesalehan Sosial". Jurnal Sosioteknologi Vol.13, Nomor 1, April 